\title{
Relationship between Factors of Construction Resources Affecting Project Cost
}

\author{
Ismail Abdul Rahman ${ }^{1}$, Aftab Hameed Memon ${ }^{1} \&$ Ahmad Tarmizi Abd. Karim ${ }^{1}$ \\ ${ }^{1}$ Faculty of Civil and Environmental Engineering, University Tun Hussein Onn Malaysia, Malaysia \\ Correspondence: Aftab Hameed Memon, Faculty of Civil and Environmental Engineering, University Tun \\ Hussein Onn Malaysia, Malaysia. Tel: 60-14-272-5620. E-mail: aftabm78@hotmail.com, aftabm78@gmail.com
}

Received: October 25, 2012

Accepted: December18, 2012 Online Published: December 25, 2012

doi:10.5539/mas.v7n1p67

URL: http://dx.doi.org/10.5539/mas.v7n1p67

\begin{abstract}
The success of any construction project highly depends on how proper and effective the management of construction resources flow. Studies show that various resources factors affected cost management and have resulted to significant amount of cost overrun worldwide. However, a few investigations had been carried out in Malaysia regarding the effect of resources in construction industry. Hence, this study focuses on identifying significant resource factors causing construction cost overrun and also assessing the relationship between these factors. Data collection was carried out through a structured questionnaire survey consisting of 20 factors identified through a comprehensive literature review. Data was analyzed using statistical software package SPSS. The Cronbach's alpha of the data was 0.910 which means that the collected data was highly reliable. The factors were ranked through mean rank approach and it was found that 3 most significant factors are "fluctuation of prices of materials", "cash flow and financial difficulties faced by contractors" and "shortages of materials". While the least significant factors in causing cost overrun are "insufficient numbers of equipment", "relationship between management and labour", and "labour absenteeism". The result of Spearman test indicates that "cash flow and financial difficulties faced by contractors" with "financial difficulties of owner" correlate strongly at a significant level of 0.752 . This identification of factors and relationships will help construction community in controlling resopurce factors for achieving project completion within the budget.
\end{abstract}

Keywords: construction management, construction resource factors, cost overrun, Johor

\section{Introduction}

Money is always of special importance to those involved in construction project. Hence, completion of any project within the estimated cost of project is the basic criteria for success of any project. The success of any project is highly depends on adequate availability and efficient management of various resources. Hence, prior and adequate arrangement for provision of resource involved in construction such as type and quantity of material, manpower, machines and finance are required at each stage of construction. There are various factors that cause failing resources management. More common, the importance of resource management is not considered properly in the conceptual and planning phases of a construction project which resulted in construction cost overrun. Therefore, this leads to the project having inadequate budget to perform its vital function. The necessity of proper budgeting for a project, an explanation of resource management, and the economic benefits that would accrue to the project are addressed. In order to control cost, equipment and labour should be utilized in the most efficient way possible.

Managing resources in the framework of civil engineering construction sector is usually an extremely complex task. Factors contribute to this complexity include the variety and great number of existing resources of both human and material, the diversity of tasks that each working unit is able to execute, the performance of each working unit, the involved costs, and the spatial distribution of all resources over the different places, leading to the need for displacement from one site to another. All these important factors imply a high number of variables, resulting in a somewhat difficult optimization process. The basic objective of resource management is to supply and support the project so that established time objectives can be met and costs can be kept within the project budget (Just \& Murphy, 1994).

In Malaysia, many projects are facing cost overrun (Ali \& Kamaruzzaman, 2010; Endut, Akintoye, \& Kelly, 2009; Sambasivan \& Soon, 2007). One of the main causes of cost overrun is ineffective resource managements. 
There are various resource related factors which lead to failure of resource management resulting in construction cost overrun. Hence, this study is aimed at investigating construction resources-related factors that cause construction cost overrun in Malaysian construction industry. However, the scope of this paper is limited to investigations in Johor state only.

\section{Related Works}

Completion of any project within the estimated cost is the basic criteria for the success of any construction project. Primary target of practitioners involved in construction projects is to complete the project within budgeted cost regardless of size and complexity of project. However, completion of any project highly depends on the construction resources. Project resources provide the means for accomplishing the work objectives (Padilla \& Carr, 1991). Construction resources management is the most important factor contributing to cost success (Meeampol \& Ogunlana, 2006).

Construction resources management has a high and significant relationship with cost performance for successful projects (Meeampol \& Ogunlana, 2006). As cited by (Zujo, Car-Pusic, \& Brkan-Vejzovic, 2010) in a multiannual research conducted in Croatia from 1996 till 1998 as part of the scientific project Construction Project Risk and Resource Management, the occurrence of price overrun was observed in no less than $81 \%$ of the projects. Previous studies reveal that there are various construction resource related factors which significantly influence construction cost. Enshassi, Al-Najjar, and Kumaraswamy (2009) found that increment of construction materials prices due to continuous border closures, delay in construction and supply of raw materials and equipment by contractors, fluctuations in the cost of building materials, and resources constraint of funds and the associated auxiliaries not ready, were among the top ten factors affecting construction cost. Financial difficulties of owner and contractor were ranked as the first problems affecting construction cost in Vietnam (Le-Hoai, Lee, \& Lee, 2008). If the contractor can minimize problems such as inefficient use and lack of construction equipment and shortage of quality material, the construction budget can be reduced (Meeampol \& Ogunlana, 2006).

In extension from the above review works in uncovering resource related factors causing cost overrun, the comprehensive literatures review work has identified a total of 20 factors which are been classified into four categories, i.e. material, manpower, machinery and money as shown in Table 1.

Table 1. Factors causing construction cost overrun

\begin{tabular}{|c|c|c|}
\hline Category & Resources-related factor & Source \\
\hline \multirow{4}{*}{ Material } & $\begin{array}{l}\text { Fluctuation of prices of } \\
\text { materials }\end{array}$ & $\begin{array}{c}\text { (Ameh, Soyingbe, \& Odusami, 2010; } \\
\text { Enshassi et al., 2009; Koushki, Al-Rashid, \& } \\
\text { Kartam, 2005) }\end{array}$ \\
\hline & Shortages of materials & $\begin{array}{l}\text { (Le-Hoai et al., 2008; Long, Ogunlana, } \\
\text { Quang, \& Lam, 2004; Omoregie \& Radford, } \\
\text { 2006) }\end{array}$ \\
\hline & $\begin{array}{l}\text { Changes in material } \\
\text { specification and type }\end{array}$ & (Moura, Teixeira, \&Pires, 2007) \\
\hline & Delay in delivery of materials & $\begin{array}{c}\text { (Creedy, 2005; Latif, Abidin, \& } \\
\text { Trigunarsyah, 2008; Moura et al., 2007) }\end{array}$ \\
\hline \multirow{6}{*}{ Manpower } & High cost of labour & $\begin{array}{l}\text { (Ameh et al., 2010; Azhar, Farooqui, \& } \\
\text { Ahmed, 2008; Koushki et al., 2005) }\end{array}$ \\
\hline & $\begin{array}{c}\text { Shortage of technical } \\
\text { personnel (skilled labour) }\end{array}$ & (Creedy, 2005) \\
\hline & Severe overtime & (Long et al., 2004) \\
\hline & Labour productivity & (Moura et al., 2007) \\
\hline & Labour absenteeism & (Moura et al., 2007) \\
\hline & Shortage of site workers & $\begin{array}{c}\text { (Ameh et al., 2010; Azhar et al., 2008; } \\
\text { Le-Hoai et al., 2008) }\end{array}$ \\
\hline \multirow{3}{*}{ Money } & Financial difficulties of owner & $\begin{array}{c}\text { (Koushki et al., 2005; Le-Hoai et al., 2008; } \\
\text { Long et al., 2004; Moura et al., 2007; } \\
\text { Oladapo, 2007) }\end{array}$ \\
\hline & $\begin{array}{l}\text { Delay payment to supplier } \\
\text { /subcontractor }\end{array}$ & (Moura et al., 2007) \\
\hline & Delay in progress payment by & (Creedy, 2005) \\
\hline
\end{tabular}




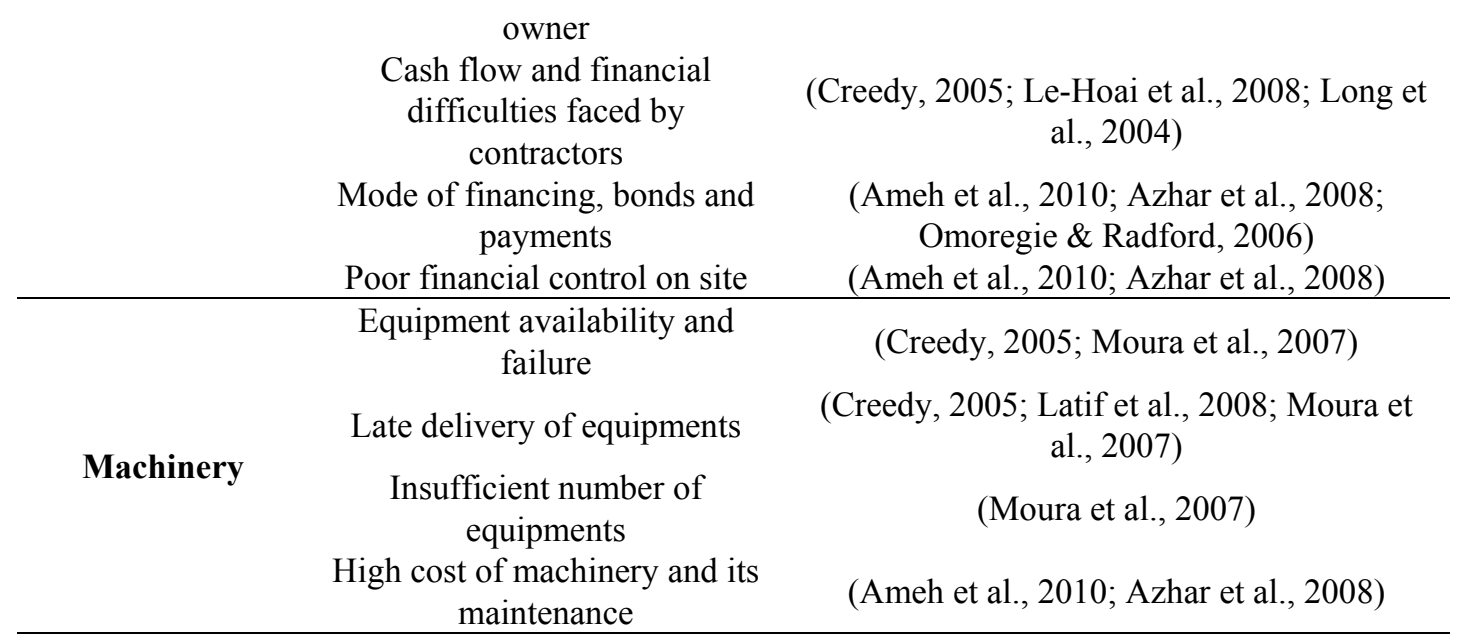

Table 1 shows 20 resource related factors which are been classified into four common types of resource groups. These resources are commonly encounted in any construction project. The resources are further discussed as in the following sections.

\subsection{Material Resource}

Materials are the essence in the construction industry which represents a substantial proportion of the total value of the project. Material related issue contributes to cost overrun run (Koushki et al., 2005). Hence, efficient material management is an important criterion for success of any project. A material management system includes the fundamental functions required in any construction project such as identifying, acquiring, storing, distributing and disposing of materials. Regular and adequate supply of the materials is very very critical tasl as late or irregular delivery or wrong types of material delivered during construction affect the utilization of other resources like manpower and machinery. This leads to poor productivity, time delay and cost overrun.

\subsection{Manpower Resource}

Manpower or human resource labour are very significant resources which play important role in success of any project. Good results certainly cannot be achieved without the adequate availability of skilled and unskilled manpower, most suitable allocation and management of human or manpower resource. Expected construction progress can be achieved only through the attainment of effective man-hour effort and the meeting of scheduled mile stone dates. Effective manpower management can reduce labour costs and thereby increase profits for company. In developing countries, poor labour productivity is a severe problem (Kaming, Olomolaiye, Holt, \& Harris, 1997). Hence, effective manpower management and improvement in labour productivity is critical need for reducing labour costs and thereby increase profits for company.

\subsection{Money or Finance}

Money or finance is the first and foremost resource required for any construction work. The design and specifications of a project depend upon it, and without sufficient fund, any project cannot be completed. Hence, availability of sufficient funds and effective financial management are very important aspects in any project. Financial management is the use of financial or accounting information at all levels to assist in planning, making decisions and controlling the activities of an enterprise (Lock, 1993). Without proper management of the money or finance, the management of other resource becomes useless.

\subsection{Machines or Equipment Resources}

Equipment Resources has an advantage over manpower resource as it can work under adverse circumstances continuously, requires less manpower and other facilities. The selection and utilization of equipment in a project must be an integral part of the total plan. The type and number of the equipments required in any project depends on the nature of the project. It affects significantly on construction cost.

\section{Methods}

Data was collected through a structured questionnaire survey carried out among the personnel involved in construction industry. The survey was conducted in Johor state of Malaysia. A total of 100 questionnaire sets were distributed and 53 completed responses were received and analyzed statistically for assessing the 
significance level of resource factors and also correlation between these factors. The tests adopted for this analysis are described in the following sections:

\subsection{Reliability Test}

A reliability test was performed on the collected data to determine its degree of consistency. The Cronbach $\alpha$ coefficient is computed for data consistency. The accepted reliability is when Cronbach $\alpha$ is greater than 0.3. If $\alpha$ is greater than 0.7, the collected data is considered as highly reliable (Wong \& Cheung, 2005; Yang \& Ou, 2008).

\subsection{Ranking}

A five point Likert-scale of 1 to 5 was adopted to assess the likelihood of each of the identified factor in causing construction cost overrun, where scales of $1=$ extremely significant, $2=$ most significant, $3=$ moderately significant, $4=$ significant, and $5=$ not significant. The studied factors were ranked based on the mean rank score. Lower mean rank score represents the higher the ranking is. The equation used to compute for the mean rank is

$$
M_{R}=\frac{n \bar{R}}{R_{\max }}
$$

Where, $\mathrm{M}_{\mathrm{R}}$ is mean rank, $\bar{R}$ is individual mean rank of cause, $\mathrm{R}_{\max }$ is the maximum individual mean rank of cause, and $\mathrm{n}$ is the number of causes. The determination of the significance of the causes is based on the mean rank score.

\subsection{Correlation Analyses}

The strength of associations of pairs of variables understudy was determined by correlation relationships. The 3 commonly used methods for ascertaining the strength of association between 2 variables is the Pearson correlation method, the Spearman rank correlation method and the Chi square test of independence method.

As data collected in this study is non-parametric and ordinal variables, the powerful method of examining the relationship between pairs of variables is by using Spearman's rank order correlation (Bryman \& Cramer, 2002). Spearman's formula is given as

$$
\rho=1-\frac{6 \sum d^{2}}{n\left(n^{2}-1\right)}
$$

where,

$\rho \quad$ Spearman coefficient

d the difference between ranks

n number of subjects or pairs of ranks

The correlation coefficient $\rho$ ranges from -1.0 to +1.0 . The closer $\rho$ is to +1 or -1 , the more closely the two variables are related. The value of $\rho$ close to 1 implies there is strong positive linear relationship between the two variables while the value of $\rho$ close to -1 shows a strong negative linear relationship between the two variables (Daud, Ahmad, \& Yusof, 2009). Ideally, the correlation coefficient value of \pm 1 is said to be a perfect correlation. If the correlation coefficient value lies between \pm 0.5 and \pm 1 , it is said to have a high degree of correlation. For correlation coefficient value between \pm 0.3 and \pm 0.5 , the degree of correlation is moderate. Low degree of correlation occurs when the correlation coefficient lies between \pm 0.1 and \pm 0.3 . Meanwhile, zero coefficient value represents no correlation at all (Cohen, 1988).

\section{Results and Discussion}

The respondents involved in the survey have had several years of experience in handling various types of projects. The demographic of the respondents participated in survey are summarized in Table 2 . The table indicates that majority of the respondents, i.e. 43 out of $53(81.1 \%)$ respondents are experienced in handling large construction projects, i.e. project with contract exceeding RM 5 million (Abdullah, Aziz, \& Rahman, 2009). $52.8 \%$ of the respondents have experience of handling building projects, $26.4 \%$ respondents are experienced in handling infrastructure project, and $20.8 \%$ respondents are involved in both building and infrastructure projects. 
Table 2. Demographic of respondents

\begin{tabular}{lccc}
\hline & Frequency & Percent & Cumulative Percent \\
\hline Type of Organization & & & \\
Client & 8 & 15.1 & 15.1 \\
Consultant & 11 & 20.8 & 35.9 \\
Contractor & 34 & 64.1 & 100 \\
Type of Project & & & \\
Building & 28 & 26.4 & 26.4 \\
Infrastructure & 11 & 52.8 & 79.2 \\
Build-Infra & 14 & 20.8 & 100 \\
Size of Project (RM) & & & \\
< - Million & 10 & 18.9 & 18.9 \\
5 - 10 Million & 10 & 18.9 & 37.8 \\
10 - 50 Million & 22 & 41.5 & 79.3 \\
$>$ 50 Million & 11 & 20.7 & 100 \\
\hline
\end{tabular}

\subsection{Reliability Test}

Data from each category of questionnaire were analyzed for its Cronbach $\alpha$ value. This was to ensure that the data collected are valid and reliable for further analysis. Cronbach $\alpha$ value for overall data was 0.910 and Table 3 shows values of Cronbach $\alpha$ for each category of the factors are in the range of 0.736 to 0.883 . This range is considered high compared to cut-off value of 0.7 . Thus, the reliability of the questionnaire is assured. Certainly, this indicates that the questionnaire data are valid and reliable.

Table 3. Reliability test results

\begin{tabular}{cc}
\hline Category of data & Cronbach $\alpha$ \\
\hline Material & 0.736 \\
Manpower & 0.745 \\
Money & 0.883 \\
Machinery & 0.760 \\
\hline
\end{tabular}

\subsection{Extent of Cost Overrun}

Respondents were asked about the extent of cost overrun as compared to the contracted cost of the various projects they have handled. The results are presented in Figure 1. Figure 1 indicates that majority of the respondents stated that cost overrun in construction projects is a common issue. Only $15.09 \%$ of the respondents testified that their projects had been executed within the estimated cost. A significant number of respondents (37.74\%) mentioned that they had experienced cost overrun ranges from $1 \%$ to $5 \%$ of contracted cost. This followed by $28.30 \%$ of the respondents stated of $5-10 \%$ of cost overrun. However, $11.32 \%$ respondents mentioned that cost overrun was above $15 \%$ of contracted cost and only $7.55 \%$ responses show that cost overrun ranging from $10 \%$ to $15 \%$.

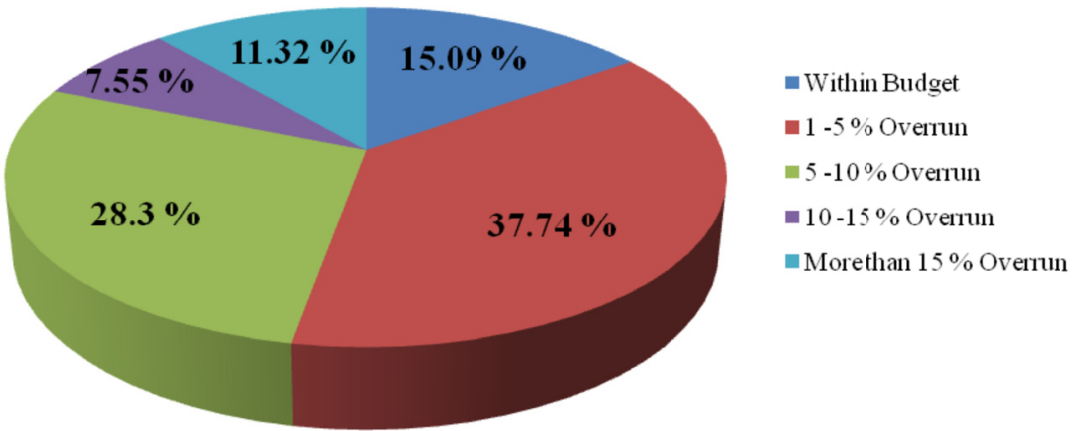

Figure 1. Extent of cost overrun 


\subsection{Ranking of Resource Related Factors}

In ranking analysis, the SPSS 17 software was used to compute the mean rank of the resource related factors causing construction cost overrun. The results of the analysis are given in Table 4.

Table 4. Rank analysis results

\begin{tabular}{lccc}
\hline \multicolumn{1}{c}{ Factor } & Mean rank & Rank & Category \\
\hline Fluctuation of prices of materials & 10.74 & 1 & Material \\
Cash flow and financial difficulties faced by contractors & 10.73 & 2 & Money \\
Shortages of materials & 10.18 & 3 & Material \\
Shortage of site workers & 10.08 & 4 & Manpower \\
Financial difficulties of owner & 9.37 & 5 & Money \\
Mode of financing, bonds and payments & 9.31 & 6 & Money \\
Changes in Material Specification and type & 8.46 & 7 & Material \\
Delay in progress payment by owner & 8.46 & 7 & Material \\
Poor financial control on site & 8.46 & 8 & Money \\
labour productivity & 8.33 & 9 & Manpower \\
Late delivery of materials & 8.24 & 10 & Material \\
Delay payment to supplier/subcontractor & 8.24 & 10 & Money \\
Late delivery of equipments & 8.20 & 11 & Machinery \\
High cost of labour & 7.89 & 12 & Manpower \\
High cost of machinery and its maintenance & 7.88 & 13 & Machinery \\
Equipment availability and failure & 7.51 & 14 & Machinery \\
Labour Absenteeism & 7.08 & 15 & Manpower \\
Shortage of technical personnel (skilled labour) & 6.71 & 16 & Manpower \\
Severe overtime & 6.70 & 17 & Manpower \\
Insufficient Numbers of equipment & 5.05 & 18 & Machinery \\
\hline
\end{tabular}

Table 4 shows that fluctuation of prices of materials is an extremely significant factor affecting construction cost. Fluctuation of material cost can be caused by various factors. Monopoly of suppliers could be one of main reasons of fluctuation of prices. Unavailability of construction materials locally can also affects the cost of material. However, Enshassi et al. (2009) ranked fluctuation of material prices as the fourth most important factors affecting construction cost in Gaza.

Second most significant factor is cash flow and financial difficulties faced by contractors. This factor has been found to be the most significant in large MARA construction projects (Memon, Rahman, Abdullah, \&Azis, 2010). Financial difficulties faced by contractor were ranked as the fourth major factor causing cost overrun in Vietnam construction industry (Le-Hoai et al., 2008). In a study of Ghana, this factor was rated as 5th major factor causing cost overrun (Frimpong, Oluwoye, \& Crawford, 2003).

The third most significant factor as indicated in Table 4 is the shortages of materials. However, previous studies have shown that this factor is moderately important factor affecting construction cost. In the study of cost escalation in Nigeria (Omoregie \& Radford, 2006) found that shortage of material was ranked as sixth significant factor. While, in Vietnamese construction projects, practitioners have ranked this factor as the 9th most significant (Le-Hoai et al., 2008). In Ghana, this factor was the 15 th significant cause affecting construction cost (Frimpong et al., 2003).

\subsection{Relationship between Factors}

Relation between pairs of variables was examined by using Spearman's rank order correlation. The correlation analysis of the factors is shown in Table 5. 
Table 5. Correlation between construction resources related factors causing cost overrun

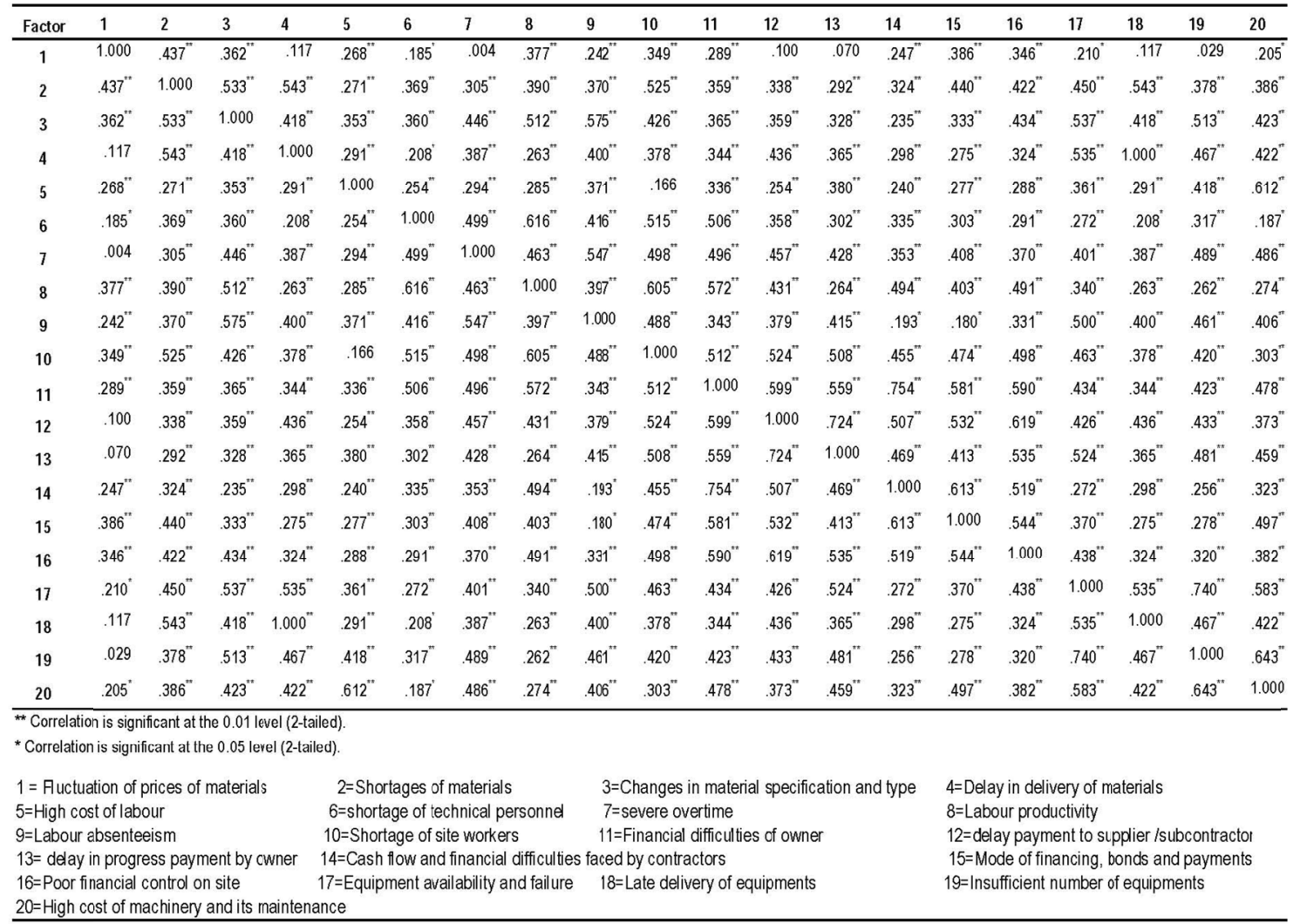

Table 5 shows that there is high degree of correlation between cash flow and financial difficulties faced by contractors, and financial difficulties of owner at a significant value of 0.752 . Also, equipment availability and failure, and insufficient numbers of equipment are highly correlated at the value of correlation 0.703 as presented graphically in Figure 2.

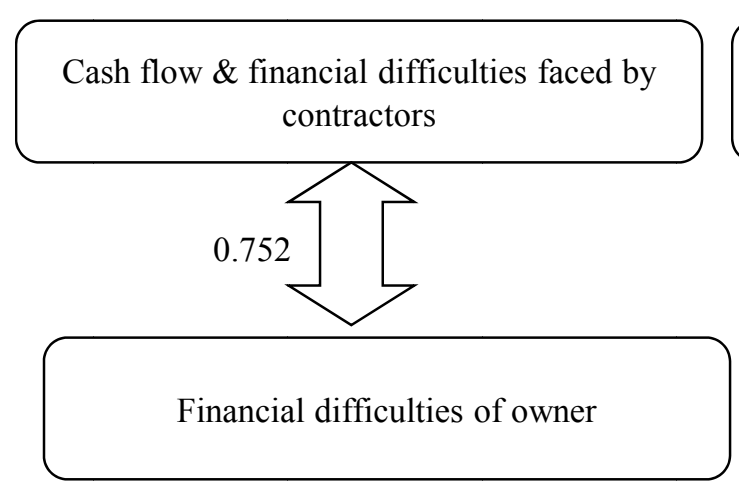

(a)

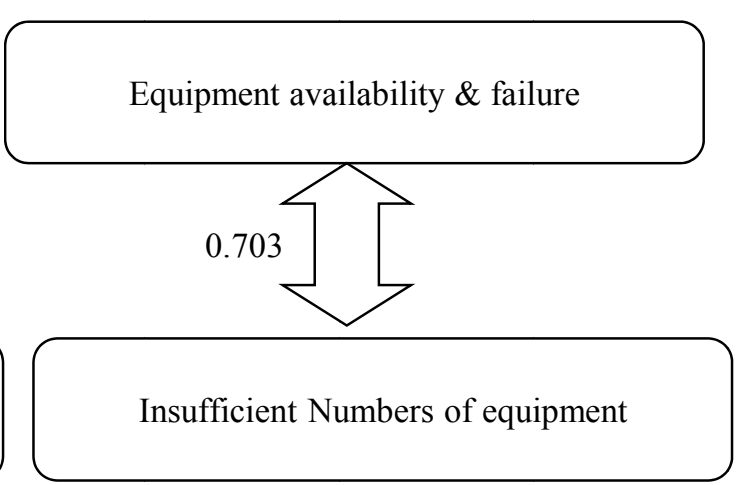

(b)

Figure 2. Relationship between factors causing cost overrun

\section{Conclusion}

The findings of the study carried out to identify the problems of cost overrun and effect of resource related factors on cost overrun in the state of Johor, Malaysia are summarized as follows:

a) About $85 \%$ of the respondents agreed that most construction projects face cost overrun problem.

b) About $11.32 \%$ projects face cost overrun above $15 \%$, where the normal range of cost overrun is between 0 and $15 \%$.

c) Fluctuation of prices of materials, cash flow and financial difficulties faced by contractors and shortages of 
materials were found as most significant factors causing cost overrun.

d) Cash flow and financial difficulties faced by contractor has strong correlation with the financial difficulties of owner.

e) Shortage of site workers, financial difficulties of owner, and cash flow and financial difficulties faced by contractors are significantly inter-correlated between each other.

f) The financial problem faced by the owner and contractor was the most critical issue in construction projects. This often leads to construction delay, and subsequently cost overrun.

g) Financial problems of contractors also influence the procurements of material and arrangement of adequate number of material and equipment. This affects labour productivity. Resolving this issue plays an important role in achieving successful projects.

\section{Acknowledgements}

The authors would like to thank Universiti Tun Hussein Onn Malaysia for supporting this study. Also, we are thankful to construction practitioners for providing comprehensive and important information, and a lot of cooperation which made data collection easier.

\section{References}

Abdullah, M. R., Aziz, A. A. A., \& Rahman, I. A. (2009). Causes of delay and its effects in large MARA construction project. International Journal of Integrated Engineering (Issue on Mechanical, Materials and Manufacturing Engineering).

Ali, A. S., \& Kamaruzzaman, S. N. (2010). Cost performance for building construction projects in Klang valley. Journal of Building Performance, 1(1), 110-118.

Ameh, O. J., Soyingbe, A. A., \& Odusami, K. T. (2010). Significant factors causing cost overruns in telecommunication projects in Nigeria. Journal of Construction in Developing Countries, 15.

Azhar, N., Farooqui, R. U., \& Ahmed, S. M. (2008). Cost Overrun Factors In Construction Industry of Pakistan. Paper presented at the First International Conference on Construction In Developing Countries (ICCIDC-I) "Advancing and Integrating Construction Education, Research \& Practice".

Bryman, A., \& Cramer, D. (2002). Quantative Data Analysis with SPSS Release 10 for Windows (2nd ed.). Taylor and Francis inc.

Cohen, J. (1988). Statistical power analysis for the behavioral sciences (2nd ed.).

Creedy, G. (2005). Risk factors leading to cost overrun in highway projects. Paper presented at the Proceeding of Queenland University of Technology Research Week International Conference, Brisbane, Australia.

Daud, Z. M., Ahmad, M. H., \& Yusof, F. (2009). Elementary Statistics. Preatice Hall, Pearson (M) Sdn Bhd.

Endut, I. R., Akintoye, A., \& Kelly, J. (2009). Cost and time overruns of projects in Malaysia. pp. 243-252. Retrieved on August 21, 2009, from http://www.irbnet.de/daten/iconda/CIB10633.pdf

Enshassi, A., Al-Najjar, J., \& Kumaraswamy, M. (2009). Delays and cost overruns in the construction projects in the Gaza Strip. Journal of Financial Management of Property and Construction, 14(2), 126-151. http://dx.doi.org/10.1108/13664380910977592

Frimpong, Y., Oluwoye, J., \& Crawford, L. (2003). Causes of delay and cost overruns in construction of groundwater projects in a developing countries; Ghana as a case study. International Journal of Project Management, 21, 321-326. http://dx.doi.org/10.1016/S0263-7863(02)00055-8

Just, M. R., \& Murphy, J. P. (1994). The effect of resource constraints on project schedules. Transaction of AACE International, Morgantown.

Koushki, P. A., Al-Rashid, K., \& Kartam, N. (2005). Delays and cost increases in the construction of private residential projects in Kuwait. Construction Management and Economics, 23(3), 285-294. http://dx.doi.org/10.1080/0144619042000326710

Latif, Y., Abidin, I., \& Trigunarsyah, B. (2008). Knowledge-based Material Cost Control for Building Construction Project using Expert System Approach. Paper presented at the CIB International Conference on Building Education and Research, Heritance Kandalama, Sri Lanka.

Le-Hoai, L., Lee, Y. D., \& Lee, J. Y. (2008). Delay and Cost Overruns in Vietnam Large Construction Projects: A Comparison with Other Selected Countries. KSCE Journal of Civil Engineering, 12(6), 367-377. 
http://dx.doi.org/10.1007/s12205-008-0367-7

Lock, D. (1993). Handbook of Engineering Management (2nd ed.). Oxford: Butterworth- Heinemann.

Long, N. D., Ogunlana, S., Quang, T., \& Lam, K. C. (2004). Large construction projects in developing countries: a case study from Vietnam. International Journal of Project Management, 22, 553-561. http://dx.doi.org/10.1016/j.ijproman.2004.03.004

Meeampol, S., \& Ogunlana, S. O. (2006). Factors affecting cost and time performance on highway construction projects: evidence from Thailand. Journal of Financial Management of Property and Construction, 11(1), 3-20. http://dx.doi.org/10.1108/13664380680001076

Memon, A. H., Rahman, I. A., Abdullah, M. R., \& Azis, A. A. A. (2010). Factors Affecting Construction Cost in MARA Large Construction Projects: Perspective of Project Management Consultants. International Journal of Sustainable Construction Engineering and Technology, 1(2), 41-54.

Moura, H. P., Teixeira, J. C., \& Pires, B. (2007). Dealing With Cost and Time in the Portuguese Construction Industry. Paper presented at the CIB World Building Congress.

Oladapo, A. A. (2007). A quantitative assessment of the cost and time impact of variation orders on construction projects. Journal of Engineering, Design and Technology, 5(1), 35-48. http://dx.doi.org/10.1108/17260530710746597

Omoregie, A., \& Radford, D. (2006). Infrastructure delays and cost escalation: Causes and effects in Nigeria. Paper presented at the Proceeding of sixth international post graduate research conference.

Padilla, M. E., \& Carr, I. R. (1991). Resource strategies for dynamic project management. Journal of $\begin{array}{lllll}\text { Construction } \quad \text { Engineering } & \text { 279-293. }\end{array}$ http://dx.doi.org/10.1061/(ASCE)0733-9364(1991)117:2(279)

Sambasivan, M., \& Soon, Y. W. (2007). Causes and effects of delays in Malaysian construction industry. $\begin{array}{llll}\text { International Journal of Project } & \text { Management, 25, }\end{array}$ http://dx.doi.org/10.1016/j.ijproman.2006.11.007

Wong, P. S. P., \& Cheung, S. O. (2005). Structural Equation Model of Trust and Partnering Success. Journal of Management in Engineering, 21(2), 70-80.

Yang, J. B., \& Ou, S. F. (2008). Using structural equation modeling to analyze relationships among key causes of delay in construction. Canadian Journal of Civil Engineering, 35, 321-332. http://dx.doi.org/10.1139/L07-101

Zujo, V., Car-Pusic, D., \& Brkan-Vejzovic, A. (2010). Contracted price overrun as contracted construction time overrun function. Technical Gazette, 17(1), 23-29. 